\title{
11: 107384855-107482789
}

National Cancer Institute

\section{Source}

National Cancer Institute. 11: 107384855-107482789. NCI Thesaurus. Code C42029.

Physical location of CUL5_Gene 